\section{Sensing of Crop Nitrogen Status: Opportunities, Tools, Limitations, and Supporting Information Requirements}

\author{
Nicolas Tremblay ${ }^{1,3}$, Edith Fallon ${ }^{1}$, and Noura Ziadi ${ }^{2}$
}

Additional InDEx words. chlorophyll meter, Dualex, reference plot

Summary. Diagnosing nitrogen (N) sufficiency in crops is used to help insure more effective management of $\mathrm{N}$ fertilizer application, and several indicators have been proposed to this end. The $\mathrm{N}$ nutrition index (NNI) offers a reliable measurement, but it is relatively difficult to determine. This index is based on the relationship between plant tissue $\mathrm{N}$ concentration and the biomass of the plant's aerial parts. However, a good estimate of the NNI should be obtained by nondestructive methods that can be carried out quickly. Although dependent on sites, chlorophyll meter (CM) measurements have been correlated with the NNI in corn (Zea mays). Since chlorophyll can be estimated through remote sensing, the possibility of quickly obtaining measurements for large surface areas points to practical applications for precision agriculture. When combined with the mapping of soil properties such as apparent electrical conductivity (EC), elevation and slope, such chlorophyll measurements make it possible to derive $\mathbf{N}$ fertilization recommendations by taking into account natural variations in the soil. Recently, an instrument called the Dualex (FORCE-A, Orsay, France) is marketed, which uses measurement methods based on the fluorescent properties of plant tissues. It is similar to the CM in terms of its operating principle but it measures polyphenolics (Phen), compounds that accumulate in the epidermis of leaves under $\mathrm{N}$ stress. Epidermal transmittance to ultraviolet light is assessed by the fluorescence excitation ratio $\mathrm{F}$ (ultraviolet)/ $\mathrm{F}$ (REF), where $\mathrm{F}$ (ultraviolet) is the fluorescence excitation detected following ultraviolet excitation, and $F(R E F)$ is the fluorescence detected on excitation at a reference wavelength, not absorbed by the epidermis. Although the Dualex generally did not identify more differences among treatments than the CM in our studies on wheat (Triticum aestivum), corn, and broccoli (Brassica olevacea ssp. italica), combining the two measurements in a chlorophyll/Phen ratio improved the relationships with crop $\mathrm{N}$ nutrition status appreciably. This ratio can also be estimated by remote sensing techniques. The NNI on its own does not constitute an economically optimal recommendation for $\mathrm{N}$ fertilizer [economically optimal $\mathrm{N}$ rate (EONR)]. The EONR is the $\mathrm{N}$ rate at which profit is greatest. Work is currently being done to use overfertilized reference plots for this purpose and to permit an improved correlation between the indicator (NNI or chlorophyll) and EONR.

$\mathrm{I}$ n light of increasing environmental concerns and the rising cost of fertilizers, the biggest challenge

This paper was part of the workshop "Improvement in Nitrogen and Water Use Efficiency: Interest of Assessment Tools" held 16 Sept. 2008 at the European Society for Agronomy Congress, Bologna, Italy.

Funding was provided by the Information Gaps in Water Quality and Nutrients (GAPS) program of Agriculture and Agri-Food Canada.

The authors would like to thank Giorgio Prosdocimi Gianquinto for having organized the Workshop "Improvement in nitrogen and water use efficiency: Interest of assessment tools," Bologna, Italy, 2008.

${ }^{1}$ Horticulture Research and Development Centre, Agriculture and Agri-Food Canada, 430 Gouin Boulevard, Saint-Jean-sur-Richelieu, Quebec, J3B 3E6, Canada

${ }^{2}$ Soils and Crops Research and Development Centre, Agriculture and Agri-Food Canada, 2560 Hochelaga Boulevard, Québec, Quebec, GIV 2J3, Canada

${ }^{3}$ Corresponding author. E-mail: Nicolas.Tremblay@ agr.gc.ca. producer's face is choosing suitable $\mathrm{N}$ management strategies to maximize profit and improve $\mathrm{N}$ use efficiency (NUE), thereby reducing environmental contamination. Economically optimal rates of $\mathrm{N}$ fertilization are the rates to maximize profits for producers (Kyveryga et al., 2007; Sawyer et al., 2006) and prevent excessive nitrate $\left(\mathrm{NO}_{3}\right)$ leaching. Yields at the EONR are slightly below maximum, but the cost of the additional fertilizer to achieve maximum yield exceeds the value of the additional yield produced. The difference between the applied $\mathrm{N}$ rate and the EONR is a strong predictor of soil water $\mathrm{NO}_{3}$ concentration and residual soil $\mathrm{NO}_{3}$ after harvest (Andraski et al., 2000). Leaching intensity is controlled by soil texture (Addiscott, 1996; van Es et al., 2002) among other factors. Heavy textures, like clays, may have a restraining influence on $\mathrm{N}$ leaching compared with sandy soil (Gustafson, 1983).

A combination of high yield expectation, variation of EONR among seasons, and relatively low fertilizer $\mathrm{N}$ costs has led producers to overapply $\mathrm{N}$ instead of considering actual crop $\mathrm{N}$ needs. Most $\mathrm{N}$ fertilizers used in the United States are applied to corn, and the main management practice for corn production in Minnesota consists of applying a relatively high single rate of $\mathrm{N}$ fertilizer over whole fields and even whole farms as a form of insurance (Sheriff, 2005) as was already stated by Schröder et al. (2000). Uncertainty is inevitable when predicting optimal rates because fertilizer is often applied before planting and because weather and other factors that come into play after fertilization influence the yield response to the added N. Successful N management requires good synchronization between the $\mathrm{N}$ supply and crop $\mathrm{N}$ requirements (Ladha et al., 2005). One approach to achieving a better match between the $\mathrm{N}$ application rate and crop $\mathrm{N}$ fertilization needs is split applications. For some vegetables like broccoli, several studies have recommended the use of split applications to increase NUE by increasing yield and minimizing $\mathrm{N}$ losses (Babik and Elkner, 2002; Riley and Vagen, 2003). A mid- to late-vegetative in-season application of $\mathrm{N}$ strategy constitutes a better match between $\mathrm{N}$ fertilization rate and crop requirements. Many alternatives exist for the split application of fertilizers, such as including surface banding, broadcasting, coulter injection, and spoke wheel injection.

Many methods have been investigated for their potential to assist in

\begin{tabular}{lllc}
\hline $\begin{array}{l}\text { Units } \\
\begin{array}{l}\text { To convert U.S. to SI, } \\
\text { multiply by }\end{array}\end{array}$ & U.S. unit & SI unit & $\begin{array}{l}\text { To convert SI to U.S., } \\
\text { multiply by }\end{array}$ \\
\hline 1.1209 & $\mathrm{lb} / \mathrm{acre}$ & $\mathrm{kg} \cdot \mathrm{ha}^{-1}$ & 0.8922 \\
0.001 & $\mathrm{ppm}$ & $\mathrm{g} \cdot \mathrm{kg}^{-1}$ & 1000 \\
2.2417 & ton $/ \mathrm{acre}$ & $\mathrm{Mg} \cdot \mathrm{ha}^{-1}$ & 0.4461
\end{tabular}


the determination of optimal $\mathrm{N}$ application rates, including soil $\mathrm{NO}_{3}$ testing (Bundy and Andraski, 1995). The crop itself provides clues about its $\mathrm{N}$ status. The critical $\mathrm{N}$ concentration $\left(\mathrm{N}_{\mathrm{c}}\right)$ model and the resulting NNI have been used as an indicator of $\mathrm{N}$ status in several crops, allowing situations of $\mathrm{N}$ nutrition deficiency and sufficiency to be identified (Bélanger et al., 2001; Justes et al., 1994; Plénet and Lemaire, 2000; Ziadi et al., 2008a). Modern sensing tools provide the ability to assess crop $\mathrm{N}$ sufficiency status as soon as the crop becomes established and as long as it is feasible to monitor canopy condition. Options for the sensing of crop $\mathrm{N}$ status include a relative assessment of chlorophyll or polyphenolics based on the $\mathrm{N}$ sufficiency index (NSI) calculated using a reference plot or strip. Sensor-based estimation of crop $\mathrm{N}$ status is a promising approach for variable-rate $\mathrm{N}$ applications and has great potential to improve NUE. Key soil characteristics (soil EC, elevation, and slope) and seasonal climatic conditions should be taken into account to ensure accurate $\mathrm{N}$ application. The purpose of this article is to discuss opportunities, tools, limitations, and supporting information requirements for the sensing of crop $\mathrm{N}$ status to improve NUE.

\section{Nitrogen nutrition index}

The $\mathrm{N}_{\mathrm{c}}$ is the minimum $\mathrm{N}$ concentration in shoots required to achieve maximum crop growth and yield (Ulrich, 1952). The concept of a critical $\mathrm{N}$ curve based on the $\mathrm{N}$ concentrations for whole plants was first developed in Europe by Lemaire and Salette (1984) for tall fescue (Festuca arundinacea). Lemaire and Salette (1984) have shown that, for grasses with a nonlimiting level of nutrition, it is possible to determine a constant relationship between percent $\mathrm{N}$ and shoot biomass (called the "critical N curve") regardless of the experimental conditions. Below this curve, $\mathrm{N}$ availability becomes a limiting factor for dry matter growth. This concept has been successfully applied to muskmelon [Cucumis melo (Fogaça et al., 2008)], processing tomato [Solanum lycopersicum (Tei et al., 2002)], potato [Solanum tuberosum (Duchenne et al., 1997)], rapeseed [Brassica napus (Colnenne et al., 1998)], and corn (Herrmann and Taube, 2004; Plénet and Lemaire, 2000). In North America
(Quebec, Canada), similar studies have been conducted for timothy [Phleum pratense (Bélanger and Gastal, 2000)], potato (Bélanger et al., 2001), and corn (Ziadi et al., 2008a).

$\mathrm{N}_{\mathrm{c}}$ is defined by the equation

$$
\mathrm{N}_{\mathrm{c}}=\mathrm{a} W^{-b},
$$

where $W$ is the total dry shoot biomass expressed in megagrams per hectare, $\mathrm{N}_{\mathrm{c}}$ is the total $\mathrm{N}$ concentration in shoots expressed in grams per kilogram dry weight (DW), and $a$ and $b$ are estimated parameters. Parameter $a$ represents the $\mathrm{N}$ concentration in the total shoot biomass at a level of 1 $\mathrm{Mg} \cdot \mathrm{ha}^{-1} \mathrm{DW}$ and parameter $b$ represents the coefficient of dilution that describes the relationship of decreasing $\mathrm{N}$ concentration with increasing shoot biomass (Bélanger and Gastal, 2000; Ziadi et al., 2008a).

Several authors have shown that $\mathrm{N}_{\mathrm{c}}$ declines as a function of aerial biomass accumulation (Duchenne et al., 1997; Justes et al., 1994; Ziadi et al., 2008a). The decrease in $\mathrm{N}$ concentration with time or with increasing biomass can be attributed to a decrease in the fraction of total plant $\mathrm{N}$ associated with photosynthesis in relation to the concomitant increase in the $\mathrm{N}$ fraction of structural and storage constituents (Bélanger and Gastal, 2000). However, during the early stages of growth (biomass $<1 \mathrm{Mg} \cdot \mathrm{ha}^{-1}$ DW), $N_{c}$ has a constant value because of the small decline of $\mathrm{N}_{\mathrm{c}}$ with increasing shoot biomass $(b=0.12$ 0.15 ) and the lack of competition for light of isolated plants (Lemaire and Gastal, 1997). Above the $1 \mathrm{Mg} \cdot \mathrm{ha}^{-1}$ DW threshold, Plénet and Lemaire (2000) in France estimated the parameters $(a=34.1$ and $b=0.37)$ in this allometric function for corn. Herrmann and Taube (2004) confirmed the critical curve developed by Plénet and Lemaire (2000), and Ziadi et al. (2008a) confirmed that the critical N curve developed in France is valid under the pedoclimatic conditions of eastern Canada.

The critical $\mathrm{N}$ curve, defined by Eq. [1], classifies $\mathrm{N}$ status in three categories (Colnenne et al., 1998). The area below the curve indicates situations where $\mathrm{N}$ is limiting growth, whereas the area above the curve indicates situations of excess $\mathrm{N}$ nutrition. Data points on or near the curve correspond to situations in which $\mathrm{N}$ concentration is optimum (Fig. 1). The NNI (Table 1) is calculated as the measured $\mathrm{N}$ concentration divided by the predicted $\mathrm{N}_{\mathrm{c}}$ (Bélanger and Gastal, 2000; Bélanger et al., 2001; Colnenne et al., 1998; Justes et al., 1994; Ziadi et al., 2008a). NNI values above 1.0 indicate a nonlimiting supply of $\mathrm{N}$, whereas values smaller than 1.0 indicate an $\mathrm{N}$ deficiency.

The NNI calculated from the curve could be a reliable indicator of the level of $\mathrm{N}$ stress during the growing

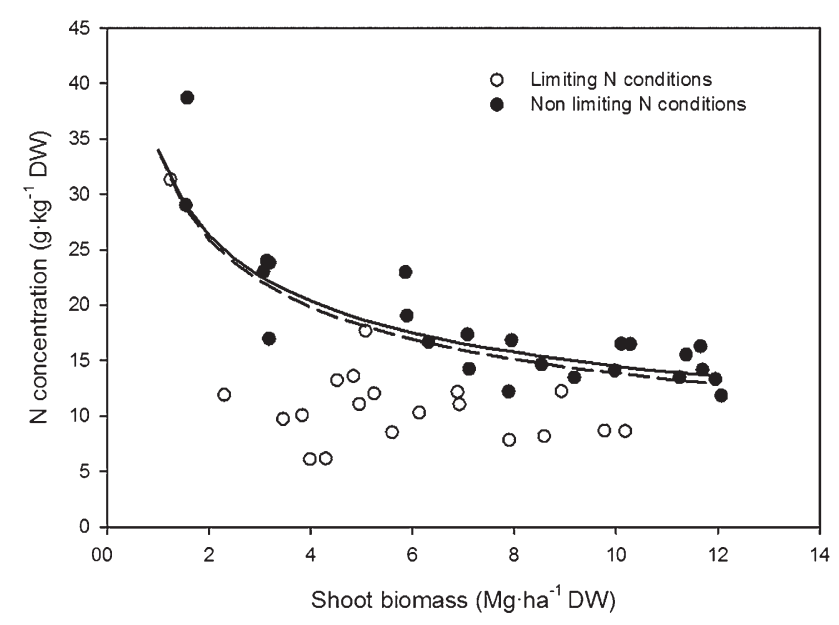

Fig. 1. Validation of the critical curve using data from corn grown under limiting and nonlimiting nitrogen $(\mathrm{N})$ growing conditions, where $\mathrm{DW}$ is dry weight. Solid line (critical $\mathrm{N}$ curve $\mathrm{N}_{\mathrm{c}}=34.0 \mathrm{~W}^{-0.37}$ ) describes the relationship between the critical $\mathrm{N}$ concentration $\left(\mathbf{N}_{\mathrm{c}}\right)$ and shoot biomass $(\mathrm{W})$ of corn in France (Plénet and Lemaire, 2000). Dashed line (critical $N$ curve $N_{c}=34.1 \mathrm{~W}^{-0.391}$ ) describes the relationship between $\mathrm{N}_{\mathrm{c}}$ and $\mathrm{W}$ of corn in Germany (Herrmann and Taube, 2004); $1 \mathrm{Mg} \cdot \mathrm{ha}^{-1}=$ 0.4461 ton $/$ acre, $1 \mathrm{~g} \cdot \mathrm{kg}^{-1}=1000 \mathrm{ppm}$ (figure from Ziadi et al., 2008a). 


\section{WORKSHOP}

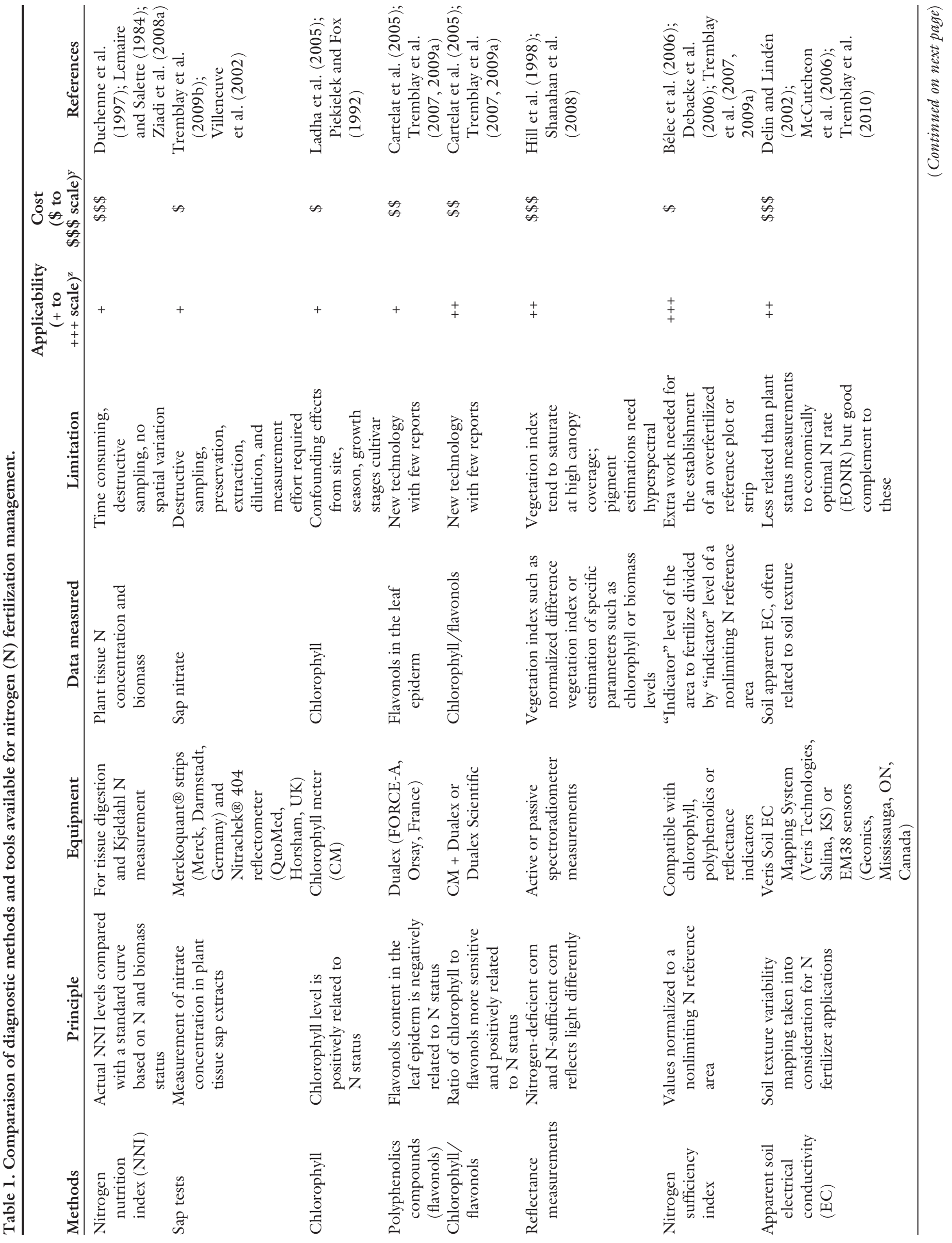




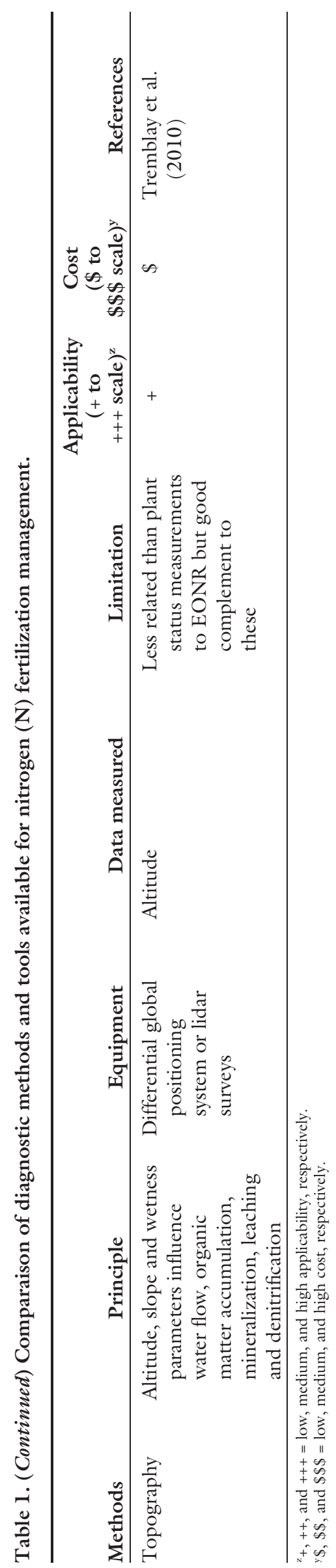

season in corn, potato, and wheat, as well as other crops (Bélanger et al., 2001; Justes et al., 1994; Ziadi et al., 2008a). However, using the NNI at farm level poses a major challenge because of the need to determine the actual crop biomass and its $\mathrm{N}$ concentration. The approach requires destructive sampling, which is time consuming. In addition, it does not provide $\mathrm{N}$ recommendations (Bélanger and Gastal, 2000; Bélanger et al., 2001; Ziadi et al., 2008a). The NNI could be used as a reference in faster, simpler, nondestructive procedures (e.g., chlorophyll measurements and remote sensing) for determining crop $\mathrm{N}$ status (Ziadi et al., 2008a).

\section{Quick tests}

SAP TESTS. The measurement of $\mathrm{NO}_{3}$ concentration in plant tissue sap extracts has been documented for a long time (Prasad and Spiers, 1984) and found useful (Matthaüs and Gysi, 2001; Villeneuve et al., 2002; Tremblay et al., 2009b) for plants with a fleshy petiole. Yet, sap tests are not widespread, presumably due to the sampling, preservation, extraction, dilution, and measurement effort required.

Chlorophyll meter. The green color of leaves is due to the pigment chlorophyll. There is a close relationship between leaf greenness and a plant's N status (Piekielek and Fox, 1992). Blackmer and Schepers (1994) evaluated different techniques for monitoring $\mathrm{N}$ status in corn, including stalk $\mathrm{NO}_{3}$ and plant sensing. They identified the CM as the best plant diagnostic tool (Table 1). It is welldocumented that $\mathrm{CM}$ readings are highly correlated with $\mathrm{N}$ concentration in corn leaf tissue (Piekielek and Fox, 1992), sugarbeet [Beta vulgaris (Sexton and Carroll, 2002)], sweet pepper [Capsicum annumm (Madeira et al., 2003)], and in other crops (Lopez-Bellido et al., 2004; Swiader and Moore, 2002). The drawback to using the CM relates to the fact that sometimes low CM readings may be caused by a deficiency in another nutrient than $\mathrm{N}$ (such as sulfur, magnesium, or iron) and the saturation of the chlorophyll level (Villeneuve et al., 2002; Westerveld et al., 2004). Indeed, chlorophyll readings reach a plateau at moderate $\mathrm{N}$ supply.

Dualex. The presence of high Phen concentrations (Table 1 ) is another indicator of $\mathrm{N}$ deficiency in a crop (Cartelat et al., 2005). A study on peppers revealed a significant inverse relationship between the leaf Phen concentration and the level of $\mathrm{N}$ fertilization (Estiarte et al., 1994). Polyphenolics play multiple roles in plants: chemical defense against herbivores and protection from ultraviolet radiation, free radicals, stress, and pathogens (Cartelat et al., 2005). Biosynthesis of Phen is regulated by biotic (e.g., insects and disease) and abiotic (ultraviolet and nutrient stress) factors (Schreiner, 2005). A new instrument called the Dualex (FORCE-A, Orsay, France) can be used for nondestructive in situ measurement of Phen concentrations in plants. For an explanation of the measurement principle, see Cartelat et al. (2005). Ideally, information from both the CM and the Dualex should be combined in a ratio (chlorophyll/Phen) to obtain an indicator providing a better range of values to compare plants with different $\mathrm{N}$ status (Table 1). Cartelat et al. (2005) were the first to propose such an indicator. Our studies have confirmed that the Dualex can be used for corn (Tremblay et al., 2007), wheat (Tremblay et al., 2009a), and broccoli (Tremblay et al., 2009b). The Multiplex 3 (FORCE-A), a new instrument capable of making remote measurements, uses the chlorophyll/Phen indicator (Zhang and Tremblay, 2010).

\section{Reflectance measurements}

Extending CM use to whole-field management is problematic since it would be not practical to collect enough data with a hand-held device to manage large fields. Even a large number of readings together represent only a small leaf area and they must be well distributed over the field or subfield. Remote sensing is a practical means of assessing spatial variability in fields across large areas (Scharf et al., 2002) (Table 1).

Nitrogen-deficient corn reflects more light over the entire visible spectrum than N-sufficient corn (Blackmer and Schepers, 1994) and usually reflects less near-IR (NIR) radiation than N-sufficient corn (McMurtrey et al., 1994). Differences in reflectance are usually greatest for wavelengths between 550 and $600 \mathrm{~nm}$ (Blackmer and Schepers, 1994; McMurtrey et al., 1994). These differences are associated with differences in leaf chlorophyll concentrations (Daughtry et al., 
2000) and can be used to guide in-season $\mathrm{N}$ management and site-specific management (Hong et al., 2006). Canopylevel observations can be made by CropScan (Rochester, MN), a spectroradiometer covering between 460 and $810 \mathrm{~nm}$ with eight spectral bands $\approx 20$ $\mathrm{nm}$ wide, centered at $460,510,560$, $610,660,710,760$, and $810 \mathrm{~nm}$ (Jongschaap, 2006).

Information about corn color obtained from aerial photographs or satellite images is potentially a better representation of the field conditions since spatially distributed information can easily be obtained over large areas. Pioneering research has shown that corn color (especially the red and green spectral regions) measured in late-season aerial photographs is quantitatively related to $\mathrm{N}$ stress and yield (Blackmer et al., 1996). Chlorophyll assessment from hyperspectral imagery has been demonstrated (Haboudane et al., 2008), and remote sensing could be used to derive NNI since estimations of both tissue $\mathrm{N}$ and biomass (W) (Chen et al., 2010) have been carried out. As of yet, very little practical use of airborne hyperspectral imagery has been shown for $\mathrm{N}$ management. However, real-time plant status estimation has been made easy from tractor-based platforms using GreenSeeker (NTech Industries, Ukiah, CA), N-Sensor/Fieldscan (Yara International, Oslo, Norway), or Crop Circle (Holland Scientific, Lincoln, $\mathrm{NE}$ ). GreenSeeker, a commercially available active light sensor, is selfilluminated in the red $[650 \pm 10 \mathrm{~nm}$, full width, half magnitude (FWHM)] and NIR $(770 \pm 15 \mathrm{~nm}$ FWHM) bands. The sensor measures the fraction of the emitted light in the sensed area that is returned to a detector, which is then used to compute normalized difference vegetation index (NDVI) (Shanahan et al., 2008). The N-Sensor/Fieldscan is a tractor mounted multispectral scanner system for variable $\mathrm{N}$ applications that has been available for about a decade in Europe as a commercial service. The newer Yara sensors use an active light technique, which is similar to the GreenSeeker system (Shanahan et al., 2008). Yara N-Sensor/Fieldscan and GreenSeeker NDVI measurements distribution have been compared in the same fields by Tremblay et al. $(2009 \mathrm{c})$ and were found to be different. The Crop Circle ACS-430 and
ACS-470 are light sensors similar to the GreenSeeker. The ACS-430 and ACS-470 are characterized by three optical measurement channels. The ACS-430 sensor measures crop and soil reflectance at 670 , 730 , and $780 \mathrm{~nm}$ simultaneously while the ACS-470 channels can be spectrally customized. The Crop Circle instruments provide a number of classic vegetative indices and recorded reflectance information from plant canopies.

\section{Usefulness of a relative assessment}

Although the CM enables users to measure leaf chlorophyll content quickly and easily, several other factors affect $C M$ values. The linear relationship between $\mathrm{CM}$ values and $\mathrm{N}$ status in crops varies with growth stages and cultivars. Also, environmental and stress factors caused by excess or limited water, deficiency of nutrients other than $\mathrm{N}$, and pests and diseases can also confound the CM readings (Ladha et al., 2005). The ability of the CM to accurately identify $\mathrm{N}$ deficiencies is improved when $\mathrm{CM}$ values are normalized to a nonlimiting $\mathrm{N}$ reference area within the same field (Debaeke et al., 2006). Westerveld et al. (2004) demonstrated that the use of a well-fertilized reference plot is appropriate for the CM meter on cabbage (Brassica oleracea ssp. capitata), onion (Allium cepa), and carrot (Daucus carota). The NSI is calculated by dividing CM readings by values obtained from nonlimiting $\mathrm{N}$ reference plots (Varvel et al., 1997) (Table 1). Research has shown that these data can be used to translate chlorophyll content into $\mathrm{N}$ management decisions, including sidedress $\mathrm{N}$ rate recommendations (Blackmer and Schepers, 1995; Varvel et al., 1997). Blackmer and Schepers (1995) reported that $\mathrm{N}$ stress and grain yield losses were observed whenever CM declined below $95 \%$ of the meter values for reference area corn receiving adequate to excess $\mathrm{N}$ at planting time. They suggested that the $95 \%$ NSI value would be a reasonable "trigger point" for applying additional N. In Quebec, Canada, a procedure using NSI measured by $\mathrm{CM}$ has been proposed for deciding how much $\mathrm{N}$ to apply at sidedress in corn. Nitrogen recommendations have been made for NSI levels ranging from $80 \%$ to $100 \%$ (Bélec et al., 2006). A better understanding of the appropriate $\mathrm{N}$ source to use in reference plot establishment, soil characteristics, and application layout (plot or strips) is needed.

Ziadi et al. (2008b) established the relationship between $\mathrm{CM}$ readings (absolute and relative NSI) and the NNI during the corn growing season. The NSI data were more closely related to the NNI $\left(R^{2}=0.61 ; P<\right.$ $0.001)$ than to raw $\mathrm{CM}$ readings $\left(R^{2}=0.53 ; P<0.001\right)$, but the intercepts and slopes of the response curves varied with site-year combinations. Hence, caution should be exercised in using these relationships to determine corn $\mathrm{N}$ status during the growing season. Debaeke et al. (2006) found a positive nonlinear relationship between NSI readings and the NNI in wheat, irrespective of year, cultivar, and growth stage. However, their experiment was conducted at a single site over a 3-year period. Unlike the NNI, the NSI cannot be used to predict grain yield and protein content when wheat is overfertilized (Debaeke et al., 2006).

The NSI provides a timely indication of EONR since a clear relationship exists between the NSI and EONR. Indeed, in a compilation of EONRs over several seasons at our L'Acadie experimental farm (N. Tremblay, E. Fallon, and N. Ziadi, unpublished data), the highest EONR was found for the lowest NSI $(80 \%)$ and vice versa. The NSI was, however, more weakly correlated with EONR above $95 \%$, which is where its potential value is greatest. Pfeffer et al. (2010) reported no workable relationship for $\mathrm{N}$ rate optimization between the relative NDVI of an area to fertilize and a reference plot either nonfertilized or overfertilized (NSI). This is unlike Tremblay et al. (2010) who demonstrated good EONR prediction from a fuzzy inference system for corn based on NSI. The system would have led to an average $\mathrm{N}$ saving of $4 \mathrm{l} \mathrm{kg} \cdot \mathrm{ha}^{-1} \mathrm{~N}$ compared with the recommended uniform rate of $170 \mathrm{~kg} \cdot \mathrm{ha}^{-1} \mathrm{~N}$, with no loss of yield. The fact that EC $\left(\mathrm{EC}_{\mathrm{a}}\right)$ was also considered by Tremblay et al. (2010) together with plant status information may have led to a better result than for Pfeffer et al. (2010). 


\section{Complementary terrain features to crop status assessment}

Geospatial measurement of $\mathrm{EC}_{\mathrm{a}}$ (Table l) is particularly useful for the spatial characterization of variability in soil-related factors, such as salinity, texture, and water content (McCutcheon et al., 2006). Apparent soil EC measuring devices provide simple and affordable soil variability measurements (James et al., 2003). There are commercially available apparent EC mapping systems (such as the VERIS 3100, Soil EC Mapping System; Veris Technologies, Salina, KS), which links soil moisture status and, therefore, textural information (McCutcheon et al., 2006). The value of $\mathrm{EC}_{\mathrm{a}}$ mapping for site-specific management is widely recognized; it is viewed as a surrogate for soil variability mapping that can be used to guide soil sampling and identify withinfield areas (or zones) of soil similarity (Taylor et al., 2003). Research clearly shows that soil water content, clay content and mineralogy, temperature, cation exchange capacity, and organic matter content are among the main soil properties affecting $\mathrm{EC}_{\mathrm{a}}$ (Friedman, 2005). Soil texture is the most important factor affecting crop growth and understanding its spatial distribution is essential to precision farming.

Topographic maps (Table 1) where agronomically important withinfield attributes can be identified are becoming increasingly available. Indeed, Schmidt et al. (2003) demonstrated how a topographic map might be obtained through repeated passes with a typical agricultural global positioning receiver.

Soil moisture will vary along a hillslope and Schmidt et al. (2007) showed a significant relationship between EONR and the change in soil water profile content. Hence, it is likely that $\mathrm{EC}_{\mathrm{a}}$ and topographic attributes influence EONR and that they should be considered for better $\mathrm{N}$ fertilizer applications. Yet, even if within-field variations in plantavailable soil $\mathrm{N}$ are affected by differences in soil characteristics, they are hard to predict from readily mapped variables. Delin and Lindén (2002) found large variations in net $\mathrm{N}$ mineralization $(\mathrm{Nm})$ both within field and between years. The within-field variations in $\mathrm{Nm}$ could be explained partly by the variation in soil organic matter content and clay content. The $\mathrm{Nm}$ pattern differed between years partly because of seasonal variations in soil moisture. For these reasons, the $\mathrm{Nm}$ pattern is difficult to predict without making adjustments for seasons (Delin and Lindén, 2002).

Previous research has indicated that $\mathrm{N}$ needs for corn vary among fields (Bundy and Andraski, 1995; Scharf et al., 2005) and within fields (Mamo et al., 2003; Scharf et al., 2005). The EONR can also vary among fields and years (Nafziger et al., 2004). Scharf et al. (2005) reported that the fieldmedian EONR over 8 site-years ranged from 63 to $208 \mathrm{~kg} \cdot \mathrm{ha}^{-1} \mathrm{~N}$, indicating that field-to-field $\mathrm{N}$ management is important for improving overall $\mathrm{N}$ management. Furthermore, the average level of within-field variability in EONR is high enough that variablerate $\mathrm{N}$ applications and use of a few soilbased management zones per field have the potential to produce economic and environmental benefits (Scharf et al., 2005). Indeed, it has been demonstrated that if the aboveground $\mathrm{N}$ surplus was close to zero, yield-scaled nitrous oxide emissions were relatively small, whereas at an $\mathrm{N}$ surplus of 90 $\mathrm{kg} \cdot \mathrm{ha}^{-1} \mathrm{~N}$, yield-scaled emissions increased 3-fold (van Groenigen et al., 2010).

In conclusion, several technologies are available to sense crop $\mathrm{N}$ status. Some have been around for some time such as the $\mathrm{CM}$ and various spectroradiometers for reflectance measurements. Even though clear relationships have been demonstrated with crop N status, their actual implementation in practice is compromised by the confounding effects on the measurements created by conditions, such as cultivars, locations, sowing dates, growing stage, weather, and the plant part sampled. The establishment of within-field reference areas and the calculation of NSI are able to standardize at least in part these confounding effects. Today, new instruments have been made available that are not measuring the usual parameters that are chlorophyll level (from $\mathrm{CM}$ ) or a mix of chlorophyll, biomass, and leaf area (from spectroradiometers). These instruments rely on fluorescence measurements to produce parameters related to leaf Phen contents and chlorophyll levels which may be used alone, or in the form of ratios
(chlorophyll/Phen) to enhance the dynamic range of the measurements with crop $\mathrm{N}$ status. In the future, all technologies will have to operate in a remote sensing setup to address the requirements for mapping crop $\mathrm{N}$ status over large areas. Indeed, spatially variable field characteristics that affect $\mathrm{N}$ releases and losses have to be accounted for their major impacts on EONR. This will allow for matching spatially based information from crop sensors to maps describing key soil and terrain attributes (soil surface textures, drainage, slopes, and wetness conditions) that are essential for EONR determination and the limitation of $\mathrm{N}$ losses in the environment. One of the main challenges in developing management strategies for $\mathrm{N}$ fertilizer applications is still the difficult-toanticipate but decisive effect of seasonal conditions on determination of actual EONR. For that matter, a better understanding of the weather effects, at least during the part of the season before sidedressing, will have to be achieved and integrated in $\mathrm{N}$ fertilization decision support system.

\section{Literature cited}

Addiscott, T. 1996. Fertilisers and nitrate leaching, p. 1-26 In: R.E. Hester and R.M. Harrison (eds.). Agricultural chemicals and the environment. Royal Society of Chemistry, London.

Andraski, T.W., L.G. Bundy, and K.R. Brye. 2000. Crop management and corn nitrogen rate effects on nitrate leaching. J. Environ. Qual. 29:1095-1103.

Babik, I. and K. Elkner. 2002. The effect of nitrogen fertilization and irrigation on yield and quality of broccoli. Acta Hort. 571:33-43.

Bélanger, G. and F. Gastal. 2000. Nitrogen utilization by forage grasses. Can. J. Plant Sci. 80:11-20.

Bélanger, G., J.R. Walsh, J.E. Richards, P.H. Milburn, and N. Ziadi. 2001. Critical nitrogen curve and nitrogen nutrition index for potato in eastern Canada. Amer. J. Potato Res. 78:355-364.

Bélec, C., N. Tremblay, H. Perrault, and L. Belzile. 2006. Le lecteur de chlorophylle, pour la juste dose d'azote dans le maï-grain. Clubs-conseils en agroenvironnement, Longueuil, QC, Canada.

Blackmer, T.M. and J.S. Schepers. 1994. Techniques for monitoring crop nitrogen status in corn. Commun. Soil Sci. Plant Anal. 25:1791-1800. 
Blackmer, T.M. and J.S. Schepers. 1995. Use of a chlorophyll meter to monitor nitrogen status and schedule fertigation for corn. J. Prod. Agr. 8:56-60.

Blackmer, T.M., J.S. Schepers, G.E. Varvel, and G.E. Meyer. 1996. Analysis of aerial photography for nitrogen stress within corn field. Agron. J. 88:729-733.

Bundy, L.G. and T.W. Andraski. 1995. Soil yield potential effects on performance of soil nitrate tests. J. Prod. Agr. 8:561-568.

Cartelat, A., Z.G. Cerovic, Y. Goulas, S. Meyer, C. Lelarge, J.L. Prioul, A. Barbottin, M.H. Jeuffroy, P. Gate, G. Agati, and I. Moya. 2005. Optically assessed contents of leaf polyphenolics and chlorophyll as indicators of nitrogen deficiency in wheat (Triticum aestipum L.). Field Crops Res. 91:35-49.

Chen, P., D. Haboudane, N. Tremblay, J. Wang, P. Vigneault, and B. Li. 2010. New spectral indicator assessing the efficiency of crop nitrogen treatment in corn and wheat. Remote Sens. Environ. 114:19871997.

Colnenne, C., J.M. Meynard, R. Reau, E. Justes, and A. Merrien. 1998. Determination of a critical nitrogen dilution curve for winter oilseed rape. Ann. Bot. (Lond.) 81:311-317.

Daughtry, C.S.T., C.L. Walthall, M.S. Kim, E. Brown de Colstoun, and J.E. McMurtrey, III. 2000. Estimating corn leaf chlorophyll concentration from leaf and canopy reflectance. Remote Sens. Environ. 74:229-239.

Debaeke, P., P. Rouet, and E. Justes. 2006. Relationship between the normalized SPAD index and the nitrogen nutrition index: Application to durum wheat. J. Plant Nutr. 29:75-92.

Delin, S. and B. Lindén. 2002. Relations between net nitrogen mineralization and soil characteristics within an arable. Acta Agriculturae Scandinavica Sect. B 52: 78-85.

Duchenne, T., J.-M. Machet, and M. Martin. 1997. Potatoes, p. 119-130. In: G. Lemaire (ed.). Diagnosis of the nitrogen status in crops. Springer-Verlag, Berlin, Germany.

Estiarte, M., I. Filella, J. Serra, and J. Peñuelas. 1994. Effects of nutrient and water stress on leaf phenolic content of peppers and susceptibility to generalist herbivore Heliocoverpa armigera (Hubner). Oecologia 99:387-391.

Fogaça, M.A. de F., J.L. Andriolo, R. Dos S. Godoi, C.A. Peixoto de Barros, D.I. Janisch, and M.A.B. Vaz. 2008. Nitrogen critical dilution curve for the muskmelon crop. Ciência Rural 38:345-350.
Friedman, S.P. 2005. Soil properties influencing apparent electrical conductivity: A review. Comput. Electron. Agr. 46:45-70.

Gustafson, A. 1983. Leaching of nitrate from arable land into groundwater in Sweden. Environ. Geology 5:65-71.

Haboudane, D., N. Tremblay, J.R. Miller, and P. Vigneault. 2008. Remote estimation of crop chlorophyll content using spectral indices derived from hyperspectral data. Inst. Electrical Electronics Eng. Trans. Geoscience Remote Sensing 46: 423-437.

Herrmann, A. and F. Taube. 2004. The range of the critical nitrogen dilution curve for maize (Zea mays L.) can be extended until silage maturity. Agron. J. 96:1131-1138.

Hill, M.J., G.E. Donald, P.J. Vickery, and R.C.G. Smith. 1998. NDVI based phonological indices; predictive potential for grazing systems. Proc. 9th Australasian Remote Sensing and Photogrammetry Conf., Univ. of New South Wales, Sydney, Australia.

Hong, N., J.G. White, R. Weisz, C.R. Crozier, M.L. Gumpertz, and D.K. Cassel. 2006. Remote sensing-informed variablerate nitrogen management of wheat and corn: Agronomic and groundwater outcomes. Agron. J. 98:327-338.

James, I.T., T.W. Waine, R.I. Bradley, J.C. Taylor, and R.J. Goldwin. 2003. Determination of soil type boundaries using electromagnetic induction scanning techniques. Biosystems Eng. 86:421-430.

Jongschaap, R.E.E. 2006. Run-time calibration of simulation models by integrating remote sensing estimates of leaf area index and canopy nitrogen. Eur. J. Agron. 24:316-324.

Justes, E., B. Mary, J.M. Meynard, J.M. Machet, and L. Thelier-Huche. 1994. Determination of a critical nitrogen dilution curve for winter wheat crops. Ann. Bot. (Lond.) 74:397-407.

Kyveryga, P.M., A.M. Blackmer, and T.F. Morris. 2007. Disaggregating model bias and variability when calculating economic optimum rates of nitrogen fertilization for corn. Agron. J. 99:1048-1056.

Ladha, J.K., H. Pathak, T.J. Krupnik, J. Six, and C. van Kessel. 2005. Efficiency of fertilizer nitrogen in cereal production: Retrospects and prospects. Adv. Agron. 87:85-156.

Lemaire, G. and F. Gastal. 1997. N uptake and distribution in plant canopies, p. 3-43. In: G. Lemaire (ed.). Diagnosis of the nitrogen status in crops. SpringerVerlag, Berlin, Germany.
Lemaire, G. and J. Salette. 1984. Relation entre dynamique de croissance et dynamique de prélèvement d'azote pour un peuplement de graminées fourragères. I. Étude de la variabilité entre génotypes. Agronomie 4:423-430.

Lopez-Bellido, R.J., C.E. Shepherd, and P.B. Barraclough. 2004. Predicting postanthesis $\mathrm{N}$ requirements of bread wheat with a Minolta SPAD meter. Eur. J. Agron. 20:313-320.

Madeira, A.C., A. Ferreira, A. De Varennes, and M.I. Vieira. 2003. SPAD meter versus tristimulus colorimeter to estimate chlorophyll content and leaf color in sweet pepper. Commun. Soil Sci. Plant Anal. 34:2461-2470.

Mamo, M., G.L. Malzer, D.J. Mulla, D.R. Huggins, and J. Strock. 2003. Spatial and temporal variation in economically optimum nitrogen rate for corn. Agron. J. 95:958-964.

Matthaüs, D. and C. Gysi. 2001. Plant sap analysis in vegetables-A tool to decide on nitrogen top dressing. Acta Hort. 563:93-102.

McCutcheon, M.C., H.J. Farahani, J.D. Stednick, G.W. Buchleiter, and T.R. Green. 2006. Effect of soil water on apparent soil electrical conductivity and texture relationships in a dryland field. Biosystems Eng. 94:19-32.

McMurtrey, J.E., III, E.W. Chappelle, M.S. Kim, J.J. Meisinger, and L.A. Corp. 1994. Distinguishing nitrogen fertilization levels in field corn (Zea mays L.) with actively induced fluorescence and passive reflectance measurements. Remote Sens. Environ. 47:36-44.

Nafziger, E.D., J.E. Sawyer, and R.G. Hoeft. 2004. Formulating N recommendations for corn in the corn belt using recent data, p. 5-11. Proc. North Central Ext.-Ind. Soil Fertility Conf, Des Moines, IA. 17-18 Nov. 2004. Potash and Phosphate Inst., Brookings, SD.

Pfeffer, A., G. Stewart, K. Janovicek, and W. Deen. 2010. Evaluation of canopy reflectance technology using a delta yield approach. Agron. J. 102:1453-1461.

Piekielek, W.P. and R.H. Fox. 1992. Use of a chlorophyll meter to predict sidedress nitrogen requirements for maize. Agron. J. 84:59-65.

Plénet, D. and G. Lemaire. 2000. Relationships between dynamics of nitrogen uptake and dry matter accumulation in maize crops. Determination of critical N concentration. Plant Soil 216:6582.

Prasad, M. and T.M. Spiers. 1984. Evaluation of a rapid method for plant sap nitrate 
analysis. Commun. Soil Sci. Plant Anal. $15: 673-679$

Riley, H. and I. Vågen. 2003. Critical Nconcentration in broccoli and cauliflower, evaluated in field trials with varying levels and timing of fertilizer. Acta Hort. 627:241-249.

Sawyer, J., E. Nafziger, G. Randall, L. Bundy, G. Rehm, and B. Joern. 2006. Concept and rationale for regional nitrogen rate guidelines for corn. 10 Nov. 2010. <http://www.extension.iastate. edu/publications/pm2015.pdf $>$.

Scharf, P.C., J.P. Schmidt, N.R. Kitchen, K.A. Sudduth, S.Y. Hong, J.A. Lory, and J.G. Davis. 2002. Remote sensing for nitrogen management. J. Soil Water Conserv. 57:518-524.

Scharf, P.C., N.R. Kitchen, K.A. Sudduth, J.G. Davis, V.C. Hubbard, and J.A. Lory. 2005. Field-scale variability in optimal nitrogen fertilizer rate for corn. Agron. J. 97:452-461.

Schmidt, J.P., N. Hong, A. Dellinger, D.B. Beegle, and H. Lin. 2007. Hillslope variability in corn response to nitrogen linked to in-season soil moisture redistribution. Agron. J. 99:229-237.

Schmidt, J.P., R.K. Taylor, and R.J. Gehl. 2003. Developing topographic maps using a sub-meter accuracy global positioning receiver. Appl. Eng. Agr. 19:291-300.

Schreiner, M. 2005. Vegetable crop management strategies to increase the quantity of phytochemicals. Eur. J. Nutr. 44:85-94.

Schröder, J.J., J.J. Neeteson, O. Oenema, and P.C. Struik 2000. Does the crop or the soil indicate how to save nitrogen in maize production? Reviewing the state of the art. Field Crops Res. 66:151-164.

Sexton, P. and J. Carroll. 2002. Comparaison of SPAD chlorophyll meter readings vs petiole nitrate concentration in sugarbeet. J. Plant Nutr. 25:1975-1985.

Shanahan, J.F., N.R. Kitchen, W.R. Raun, and J.S. Schepers. 2008. Responsive inseason nitrogen management for cereals. Comput. Electron. Agr. 61:51-62.
Sheriff, G. 2005. Efficient waste? Why farmers over-apply nutrients and implications for the policy design. Rev. Agr. Econ. 27:542-557.

Swiader, J.M. and A. Moore. 2002. SPAD-chlorophyll response to nitrogen fertilization and evaluation of nitrogen status in dryland and irrigated pumpkins. J. Plant Nutr. 25:1089-1100.

Taylor, J.C., G.A. Wood, R. Earl, and R.J. Godwin. 2003. Soil factors and their influence on within-field crop variability; Part II: Spatial analysis and determination of management zones. Biosystems Eng. $84: 441-453$.

Tei, F., P. Benincasa, and M. Guiducci. 2002. Critical nitrogen concentration in processing tomato. Eur. J. Agron. $18: 45-55$.

Tremblay, N., M.Y. Bouroubi, B. Panneton, S. Guillaume, P. Vigneault, and C. Bélec. 2010. Development and validation of fuzzy logic inference to determine optimum rates of $\mathrm{N}$ for corn on the basis of field and crop features. Precis. Agr. 11: 621-635.

Tremblay, N., Z. Wang, and C. Bélec. 2007. Evaluation of the Dualex for the assessment of corn nitrogen status. J. Plant Nutr. 30:1355-1369.

Tremblay, N., Z. Wang, and C. Bélec. 2009a. Performance of Dualex in spring wheat (Triticum aestivum L.) for crop nitrogen status assessment, yield prediction and estimation of soil nitrate content. J. Plant Nutr. 33:57-70.

Tremblay, N., C. Bélec, S. Jenni, E. Fortier, and R. Mellgren. 2009b. The Dualex - A new tool to determine nitrogen sufficiency in broccoli. Acta Hort. 824:121-131.

Tremblay, N., Z. Wang, B.-L. Ma, C. Bélec, and P. Vigneault. 2009c. A comparaison of crop data measured by two commercial sensors for variable-rate nitrogen application. Precis. Agr. 10:145161.

Ulrich, A. 1952. Physiological bases for assessing the nutritional requirements of plants. Annu. Rev. Plant Physiol. 3:207228 .

van Es, H.M., K.J. Czymmek, and Q.M. Ketterings. 2002. Management effects on nitrogen leaching and guidelines for a nitrogen leaching index in New York. J. Soil Water Conserv. 57:499-504.

van Groenigen, J.W., G.L. Velthof, O. Oenema, K.J. van Groenigen, and C. van Kessel. 2010. Towards an agronomic assessment of $\mathrm{N}_{2} \mathrm{O}$ emissions: A case study for arable crops. Eur. J. Soil Sci. 61:903-913

Varvel, G.E., J.S. Schepers, and D.D. Francis. 1997. Ability for in-season correction of nitrogen deficiency in corn using chlorophyll meters. Soil Sci. Soc. Amer. J. 61:1233-1239.

Villeneuve, S., J. Coulombe, C. Belec, and N. Tremblay. 2002. A comparison of sap nitrate test and chlorophyll meter for nitrogen status diagnosis in broccoli (Brassica oleracea L. ssp. italica). Acta Hort. 571:171-177.

Westerveld, S.M., A.W. McKeown, C.D. Scott-Dupree, and M.R. McDonald. 2004. Assessment of chlorophyll and nitrate meters as field tissue nitrogen tests for cabbage, onions and carrots. HortTechnology 14:179-188.

Zhang, Y.P. and N. Tremblay. 2010. Evaluation of the Multiplex ${ }^{\circledR}$ fluorescence sensor for the assessment of corn nitrogen status. Proc. 10th Intl. Conf. on Precision Agriculture. Denver, CO, 18-21 July 2010. Paper no. 396.

Ziadi, N., M. Brassard, G. Bélanger, A.N. Cambouris, N. Tremblay, M.C. Nolin, A. Claessens, and L.E. Parent. 2008a. Critical nitrogen curve and nitrogen nutrition index for corn in eastern Canada. Agron. J. 100:271-276.

Ziadi, N., M. Brassard, G. Bélanger, A. Claessens, N. Tremblay, A.N. Cambouris, M.C. Nolin, and L.E. Parent. 2008b. Chlorophyll measurements and nitrogen nutrition index for the evaluation of corn nitrogen status. Agron. J. 100:12641273. 